\title{
Effects of the essential oil obtained from Pilocarpus spicatus Saint-Hilaire (Rutaceae) on the development of Rhodnius prolixus nymphae
}

\author{
Cícero B. Mello ${ }^{1}$, Cléber D. Uzeda ${ }^{1}$, Marana V. Bernardino ${ }^{1}$, Duclécio Mendonça-Lopes ${ }^{1}$, \\ Alphonse Kelecom ${ }^{1}$, Paulo C. A. Fevereiro', Marcelo S. Guerra ${ }^{2}$, Adriana P. Oliveira ${ }^{3}$, \\ Leandro M. Rocha ${ }^{4}$, Marcelo S. Gonzalez ${ }^{1 *}$ \\ ${ }^{1}$ Departamento de Biologia Geral, Instituto de Biologia, Universidade Federal Fluminense, Morro do \\ Valonguinho s/n, 24001-970, Niterói, RJ, Brazil, \\ ${ }^{2}$ Departamento de Ciências, Faculdade de Formação de Professores, Universidade do Estado do Rio de Janeiro, \\ Rua Dr. Francisco Portela, 24435-000, São Gonçalo, RJ, Brazil, \\ ${ }^{3}$ Núcleo de Pesquisa de Produtos Naturais, Centro de Ciências da Saúde, Universidade Federal do Rio de \\ Janeiro, Ilha do Fundão, 21941-590, Rio de janeiro, RJ, Brazil, \\ ${ }^{4}$ Laboratório de Tecnologia de Produtos Naturais, Departamento de Tecnologia Farmacêutica, Universidade \\ Federal Fluminense, Rua Mário Viana 523, Santa Rosa, Niterói, RJ, Brazil
}

\begin{abstract}
RESUMO: "Efeitos do óleo essencial de Pilocarpus spicatus Saint-Hilaire (Rutaceae) no desenvolvimento de ninfas de Rhodnius prolixus". Bioensaios contra ninfas de $5^{\circ}$ estádio de Rhodnius prolixus foram conduzidos utilizando-se óleo essencial de Pilocarpus spicatus extraído por hidrodestilação. Os principais resultados podem ser resumidos como se segue: (i) altos níveis de toxicidade e paralisia associados à discreta inibição da muda foram induzidos pela aplicação tópica de $0,5 \mu \mathrm{L}$ ou $1,0 \mu \mathrm{L}$ do óleo essencial por inseto; (ii) fagoinibição parcial, altos níveis de inibição da muda, período intermuda prolongado e alto número de insetos paralisados mas ausência de toxicidade foram observados após tratamento oral com 5,0 $\mu \mathrm{L}$ ou $10 \mu \mathrm{L}$ de óleo essencial de P. spicatus por $\mathrm{mL}$ de sangue ingerido. A importância destes resultados em relação a eventos biológicos relevantes em $R$. prolixus é aqui discutida.
\end{abstract}

Unitermos: Rhodnius prolixus, Pilocarpus spicatus, óleo essencial.

\begin{abstract}
Bioassays against fifth-instar nymphae of Rhodnius prolixus were conducted with essential oil of Pilocarpus spicatus extracted by hydrodistillation. The main results may be summarized as follows: (i) high levels of toxicity and paralysis together with discrete moulting inhibition were caused by topical application of either $0.5 \mu \mathrm{L}$ or $1.0 \mu \mathrm{L}$ per insect of the crude essential oil; (ii) partial fagoinhibition, high moulting inhibition, prolonged intermoulting period and high number of paralyzed insects, but no toxicity were observed after oral treatment using either $5 \mu \mathrm{L}$ or $10 \mu \mathrm{L}$ of Pilocarpus spilcatus essential oil per $\mathrm{mL}$ of ingested blood meal. The importance of these results in relation to the relevant biological events in $R$. prolixus is herein discussed.
\end{abstract}

Keywords: Rhodnius prolixus, Pilocarpus spicatus, essential oil.

\section{INTRODUCTION}

It is long known that secondary plant metabolites are important molecules involved in the coevolutionary mechanisms of interaction with other organisms, mainly insects (Fraenkel, 1959; Ehrlich; Raven, 1964; Jermy, 1966; Bowers, 1984; Edwards; Wratten, 1981). Some of these secondary metabolites are able to directly disrupt specific physiological routes related with neuroendocrine and feeding systems, metamorphosis, reproduction, diapausis and behavior of arthropods, constituting vulnerable points for the population control based on the life cycle of insects vectors (Stoka, 1987, Kelecom et al., 2002a,b, Garcia; Azambuja, 2004). Undoubtedly, the defense mechanisms of plants includes antifeedant and repellent as well as hormones and antihormones principles acting as insect growth regulators that could be useful for both the protection of agricultural plants and the control of insect vectors with medical and veterinary importance, such as mosquitoes, flies, triatomines and fleas (Mulla; Su, 1999; Garcia; Azambuja, 2004).

Although many plant families have been screened, little is known about the effects of compounds derived from the family Rutaceae on the development 
of arthropods (Craveiro et al., 1981; Guenter, 1972; Lahiou, 2004). Pilocarpus is a neotropical genus of arboreous plants, comprising 16 species, ranging from southern Mexico and Central America to the south of south America. Thirteen species occur in Brazil, 11 of them endemic. Most species are found in the North, Northeast and East of Brazil (Skopura, 1996). Species of Pilocarpus represents in Brazil one of the most important sources of pharmacologically active compounds (see discussion) and also accumulate other groups of secondary metabolites such as essential oils (Skopura et al., 1998). Thus, species of the genus Pilocarpus are interesting candidates to utilization in control programs against insect vector populations.

Rhodnius prolixus, an important Chagas' disease vector in America, is traditionally used as a model for studies of insect physiology (Wigglesworth, 1934a,b, 1943; 1972; Garcia et al., 1990), control vector strategies (Garcia; Azambuja, 2004) and vector parasite interactions (Chagas, 1909; Dias, 1943; Garcia; Azambuja, 1991; Garcia et al., 1999; Gonzalez et al., 1999, 2000; Kollien; Schaub, 2000; Cortez et al., 2002; Kelecom et al., 2002a). In this work, studies were carried out with the essential oil obtained from Pilocarpus spicatus plants (popularly know as "Jaborandi da restinga") - collected in natura in the state of Rio de Janeiro (Brazil) - looking for effects produced on blood ingestion, mortality, molt and movement of fifth-instar nynphae of $R$. prolixus.

\section{MATERIAL AND METHODS}

\section{Insect rearing and feeding procedures}

Fifth-instar nymphae of male Rhodnius prolixus (Hemiptera: Reduviidae) were reared and maintained in the laboratory at $28^{\circ} \mathrm{C}$ and relative humidity of $60-70 \%$, as described by Azambuja and Garcia (1997). Randomly chosen insects from different experimental groups were then allowed to feed upon a membrane apparatus (Garcia et al., 1984) and submitted to the biological assays (see below).

\section{Collection of Pilocarpus spicatus}

The specimens of $P$. spicatus Saint-Hilaire (Rutaceae) were harvested during springtime (October) in the afternoon (5 p.m.) from the border of the periodically flooded forest formation of the sandbank coastal plain of Restinga de Jurubatiba National Park (county of Carapebus), located on the Atlantic coast of

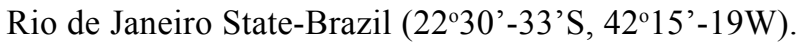
The dried herbarium specimens were both identified and deposited concomitantly in the Herbarium of the Faculdade de Formação de Professores (Universidade do Estado do Rio de Janeiro-UERJ) and in the Herbarium of the Departamento de Biologia Geral (Universidade
Federal Fluminense-UFF) under the signature of $\mathrm{M}$. Guerra Santos and P. Ayres Fevereiro ( $\mathrm{n}^{\circ}$ 1824). The specimens of Pilocarpus spicatus were identified according Kaastra (1982) by comparison with others specimens in the Herbarium of the Museu Nacional (Universidade Federal do Rio de Janeiro).

\section{Extraction of essential oil from Pilocarpus spicatus}

The essential oil extract $(5.5 \mathrm{~mL})$ was obtained from whole P. spicatus fresh leaves $(741 \mathrm{~g})$ by hydrodistillation during 6 hours at room temperature using a modified Clevenger's equipment (Gotlieb; Magalhães, 1960).

\section{Biological assays}

Following ecdysis, fifth-instar nymphae of male $R$. prolixus were starved for 25 days. Insects were then submitted to three different approaches. In the control group I insects were only fully engorged on citrated whole human blood. Doses of $0.5 \mu \mathrm{L}$ and 1.0 $\mu \mathrm{L}$ per insect of the crude $P$. spicatus essential oil were used for the topical treatment and applied directly to the ventral surface of the abdomen immediately after feeding. Feeding treatment with $P$. spicatus oil was performed by adding different amounts of the crude essential oil to reach final concentrations of $5 \mu \mathrm{L}$ and $10 \mu \mathrm{L} / \mathrm{mL}$ to the blood meal. To compare the effect of blood meal alone on the moult process during feeding treatment assays, partially-fed insects (control II) had a deliberated interrupted feeding in such a way to ingest the same amount of human blood than P. spicatus-fed insects. Except for these groups, only fully engorged insects were used throughout the experiments. The biological evaluation of the different treatments were recorded by weight of ingested blood, toxicity (i.e., $24 \mathrm{~h}$ mortality), intermoulting period (range), ecdysis and paralysis, which was determined by the absence of response to checking withdrawal reflex after application of a delicate pressure to the legs with forceps and watching the capacity of the antennae to be extended as well as by the absence of nymph movement (Garcia et al., 1990). All experiments were repeated at least in triplicate with batches of 50 insects.

\section{Data analysis}

Significance of the results was analyzed using ANOVA and Turkey's test (Armitage et al., 2002) according to Stats Direct Statistical Software, version 2.2.7 for Windows 98. Differences between treated and control insects were considered not statistically significant when $p>0.05$. Probability levels are specified in the text.

\section{RESULTS}




\section{Topical treatment}

Table 1 shows that topical treatment with $P$. spicatus essential oil caused high mortality of 90.5 and $91.1 \%$ in 24 hours at doses of $0.5 \mu \mathrm{L}$ and $1.0 \mu \mathrm{L} /$ insect, respectively, whereas only $5.5 \%$ of control insects died at the end of the experiments $(p<0.0001)$. For both doses, the intermoulting cycle (4 days) was not altered and $81 \%$ of surviving insects moult to adult stage while control group presented $100 \%$ of ecdysis $(\mathrm{p}<$ 0.01 ). No paralysis was observed in the control group. On the contrary, doses of $0.5 \mu \mathrm{L}$ and $1.0 \mu \mathrm{L} /$ insect induced paralysis in $89 \%$ and $92 \%$ of surviving treated insects, respectively, lasting 15 days after starting the experiments $(\mathrm{p}<0.0001)$. After that period, all treatednymphae recovered normal movement.

\section{Feeding treatment}

As seen in Table 2, orally given $P$. spicatus essential oil had significant feeding inhibition effect at concentrations of $5.0 \mu \mathrm{L}$ and $10.0 \mu \mathrm{L} / \mathrm{mL}$ of blood meal (168.3 and $171.7 \mathrm{mg}$ of ingested blood, respectively) when comparing with fully engorged control group insects $(239,7 \mathrm{mg})(\mathrm{p}<0.01)$. No significant difference was determined between partially-fed control insects $(170,9 \mathrm{mg})$ and Pilocarpus-fed insects $(\mathrm{p}>0.05)$. Also, no significant mortality effects were detected by any applied treatment used $(\mathrm{p}>0.05)$. Complete ecdysis in fully engorged control group occurred between 12-16 days after feeding whereas the intermoulting period had been prolonged to 6 days in partially-fed control insects and in all Pilocarpus-fed experimental groups $(\mathrm{p}<0.01)$. While only $57.4 \%$ of survived partially-fed insects reached the adult stage if compared with $100 \%$, in surviving fully engorged nymphs $(\mathrm{p}<0.001)$, the higher inhibition of ecdysis (5.3 and 3.2\% of molt in surviving nymphs) were detected for both concentrations of $P$. spicatus essential oil tested, respectively $(\mathrm{p}<0.0001)$. Despite they had ingested approximately the same amount of blood than partially-fed insects $(170.9 \mathrm{mg})$, Pilocarpus-fed insects displayed significant less ecdysis $(\mathrm{p}<0.001)$. In the same way, high level of lethargic Pilocarpus-fed insects (91-93\%) were observed along 15 days after starting the experiments when compared with control groups where no paralysis was detected ( $p$ $<0.0001)$.

The most pronounced biological effects obtained after topical or feeding treatment with $P$. spicatus essential oil on $R$. prolixus nymphs are summarized in Table 3.

\section{DISCUSSION AND CONCLUSION}

Whole plants or different parts as well as isolated compounds obtained from the genus Pilocarpus have been traditionally used in medical therapy for a variety of ophthalmic and geriatric human diseases (Craveiro et al., 1979, 1981; Link et al., 1974; Avancini et al., 2003; Taveira et al., 2003; Andrade-Neto et al., 2002; Bertrand et al., 2001; Krause et al., 1986; Bohm; Fabel, 1987; Wamil, et al. 1989, Leto, 1991, Yermakova et al., 1991; Riedler, 1992; Bodner; Gorsky, 1996; Rosche et al., 1997; Hoffman; Zang, 1999; Auffarth et al., 2002; Agra et al., 2007). In the same way, some Pilocarpus-obtained compounds also act as antidotes on intoxication by Datura stramonium (Salyi; Abonyi, 1994), induce spittling (Kempf, 1999) and have in vitro action against Pseudomonas aeruginosa, Staphylococcus aereus and Trypanosoma cruzi (Santos et al., 1997; Vieira et al., 2001; Mafezoli et al., 2000; Pavão et al., 2002). Essential oil extracted from a variety of host plants (Guenter, 1972) have been recently reported on account of their effects on the development and behavior of insects as Trialeurodes vaporariorum (Choi et al., 2003), Tribolium confusum (Tunc; Erler, 2003), mosquito species (Tuetun et al., 2004; Costa et al., 2005; Pimenta et al., 2006), Triatoma infestans and Rhodnius neglectus (Fournet et al., 1996; Laurent et al., 1997; Vilaseca et al., 2004), Pediculus humanus (Cestari et al., 2004), Oxyops vitiosa (Wheeler, 2005), Meligethes aeneus (Mauchline et al., 2005) and Lobesia botrana (Katerinopoulos et al., 2005). Despite the wellknown use of Rutaceae plants for a diversity of diseases, only the feeding deterrence induced in Spodoptera litoralis by some furanocoumarins obtained from Pilocarpus goudotianus (Calcagno et al., 2002) were studied in insects with economic importance. From our results, only a single topical application of 0.5 or 1.0 $\mu \mathrm{L}$ of the crude essential oil of $P$. spicatus per nymph induced high mortality (90.5 and $91.1 \%$ respectively) in $R$. prolixus. On the other hand, an oral concentration of up to $10 \mu \mathrm{L}$ of the essential oil per ml of blood meal (dose nearby $1.72 \mu \mathrm{L}$ per nymph) had no significant effect on insect's mortality. Moreover, considering the survived treated-nymph, a high number of insects (around 90\%) were induced to temporary paralysis by both topical and oral assays at all concentrations tested. As neither mortality nor paralysis were observed after topical application of non-toxic vegetable oil on $R$. prolixus nymph (not shown), it is reasonable to suppose that the P. spicatus topical effects are not due to physical properties of the oil (i.e., inducing of impervious cuticle which blocks insect respiration and/or movement, etc) but, perhaps the substances in the essential oil ingested during feeding treatment may be better metabolized by the triatomine digestive system than by the cutaneous route before reaching the haemolymph and/or other target-organs. However, nothing is known about cuticle or gut absorption of any Pilocarpus-derived compound in insects. In the feeding treatment, both doses of $P$. spicatus essential oil had a feeding deterrent effect. In the same way, only $57.4 \%$ of the on purpose partiallyfed insects had molt when compared with $100 \%$ of 
Table 1. Biological evaluation of the topical treatment with essential oil obtained from Pilocarpus spicatus on the development of male Rhodnius prolixus fifth- instar nymph.

\begin{tabular}{|c|c|c|c|c|c|}
\hline Groups & $\begin{array}{l}\text { Ingested blood } \\
\qquad(\mathrm{mg})\end{array}$ & $\begin{array}{l}\text { Mortality } \\
24 \mathrm{~h}(\%)\end{array}$ & $\begin{array}{c}\text { Moult of } \\
\text { Surviving } \\
\text { Nymphae (\%) }\end{array}$ & $\begin{array}{c}\text { Moulting } \\
\text { Period (range) }\end{array}$ & $\begin{array}{c}\text { Paralysis } \\
\text { during } 15 \text { days } \\
\text { after blood } \\
\text { meal }(\%)\end{array}$ \\
\hline Control & $233.7 \pm 16.4$ & $5.5 \pm 4.0$ & 100 & $12-16$ & 0 \\
\hline $\begin{array}{l}P \text {. spicatus essential oil }(0.5 \mu \mathrm{L} \\
\text { per insect })\end{array}$ & $231.9 \pm 15.4$ & $90.5 \pm 3.1$ & $81.3 \pm 12.8$ & $12-16$ & $89 \pm 3.4$ \\
\hline $\begin{array}{l}P \text {. spicatus essential oil }(1.0 \mu \mathrm{L} \\
\text { per insect) }\end{array}$ & $231.7 \pm 16.2$ & $91.1 \pm 3.4$ & $81.6 \pm 13.3$ & $12-16$ & $92 \pm 4.4$ \\
\hline
\end{tabular}

Table 2. Biological evaluation of the feeding treatment with essential oil from Pilocarpus spicatus on the development of male Rhodnius prolixus fifth-instar nymph.

\begin{tabular}{|c|c|c|c|c|c|}
\hline Groups & $\begin{array}{l}\text { Ingested blood } \\
\qquad(\mathrm{mg})\end{array}$ & $\begin{array}{l}\text { Mortality in } 24 \\
\mathrm{~h}(\%)\end{array}$ & $\begin{array}{c}\text { Moult of } \\
\text { Surviving } \\
\text { Nymphae }(\%)\end{array}$ & $\begin{array}{c}\text { Moulting } \\
\text { Period (range) }\end{array}$ & $\begin{array}{l}\text { Paralysis } \\
\text { during } 15 \text { days } \\
\text { after blood } \\
\text { meal }(\%)\end{array}$ \\
\hline $\begin{array}{l}\text { Control 1: fully } \\
\text { engorged insects }\end{array}$ & $239.7 \pm 15.4$ & $5.5 \pm 4.0$ & 100 & $12-16$ & (2) \\
\hline Control 2: partially fed insects & $170.9 \pm 6.4$ & $5.0 \pm 3.1$ & $57.4 \pm 10.6$ & $12-18$ & 0 \\
\hline $\begin{array}{l}\text { P. spicatus essential oil ( } 5.0 \\
\mu \mathrm{L} / \mathrm{mL} \text { blood meal })\end{array}$ & $168.3 \pm 7.5$ & $4.9 \pm 3.4$ & $5.3 \pm 0.88$ & $12-18$ & $93 \pm 5.1$ \\
\hline $\begin{array}{l}\text { P. spicatus essential oil ( } 10.0 \\
\mu \mathrm{L} / \mathrm{mL} \text { blood meal })\end{array}$ & $171.7 \pm 7.7$ & $5.2 \pm 3.1$ & $3.2 \pm 0.53$ & $12-18$ & $91 \pm 7.2$ \\
\hline
\end{tabular}

Table 3. Most pronounced biological effects after topical or feeding treatment with essential oil obtained from Pilocarpus spicatus on the development of male Rhodnius prolixus fifth- instar nymph.

\begin{tabular}{|c|c|c|c|c|}
\hline Mortality in $24 \mathrm{~h}$ & Feeding inhibition & Moult inhibition & $\begin{array}{l}\text { Prolonged moulting } \\
\text { period }\end{array}$ & $\begin{array}{l}\text { Paralysis during } 15 \\
\text { days after blood } \\
\text { meal }\end{array}$ \\
\hline $\begin{array}{l}91.1 \pm 3.4 \% \\
\text {-Topical treatment } 1.0 \\
\mu \mathrm{L} / \mathrm{mL} \text { per nymph }\end{array}$ & $\begin{array}{l}29.7 \pm 1.3 \% \\
\text {-Feeding treatment } \\
5 \mathrm{uL} / \mathrm{mL} \\
\text { ingested blood }\end{array}$ & $\begin{array}{l}96.8 \pm 0.1 \% \\
\text {-Feeding treatment } 10 \\
\mu \mathrm{L} / \mathrm{mL} \\
\text { ingested blood }\end{array}$ & $\begin{array}{l}48 \mathrm{~h} \text { more } \\
\text {-Feeding treatment } \\
5-10 \mu \mathrm{L} / \mathrm{mL} \\
\text { ingested blood }\end{array}$ & $\begin{array}{l}93 \pm 5,1 \% \\
\text {-Feeding treatment } \\
5 \mu \mathrm{L} / \mathrm{mL} \\
\text { ingested blood }\end{array}$ \\
\hline
\end{tabular}

ecdysis observed in the control group. However, despite feeding is considered a fundamental pre-requisite for ecdysis (Wigglesworth, 1934a,b), the antifeedant effect of oral administered P. spicatus essential oil does not explain alone the high moult inhibition observed since partially-fed insects, which ingested the same amount of blood, molted nearly 10 times more than Pilocarpusfed insects. On the contrary, the intermoulting period was extended in both Pilocarpus-fed and partiallyfed insects pointing out the importance of the amount of ingested blood for the molting range as described by Wigglesworth (1943) and Garcia (1987). On the other side, only a discrete molt inhibition without alteration of intermoulting period was induced by the topical treatment. Therefore, both molt inhibition and transitory paralysis triggered by topical and feeding treatments are related not only to toxicity but, probably also due interference of Pilocarpus compounds on the triatomine neuroendocrine system, once ecdysis and insect movement are under neurological control (Wigglesworth, 1934a,b, 1972; Lazzari, 1992; TakanoLee; Edman, 2001). Unfortunately, despite many essential oils have been extracted and analyzed, and a number of components identified, little is know about their useful biological activities (Lahiou, 2004). Thus, chemical substances such as episesamin, hesperidin, pilocarpin, imidazole, 2-tridecadone, alpha-cadinol, spathulenol, eugenol, and classes of metabolites such as flavonoids, terpenoids, coumarins, alkaloids and others have been described for different species of the genus Pilocarpus (Craveiro et al., 1979; Amaro Luis et al., 1990; Andrade-Neto et al., 1996, 2000; Bertrand et al., 2001, Lúcio et al., 2002; Santos et al., 2004) and deserve biological screening. Specially, volatile constituents of P. spicatus essential oil, such as aliphatic ketones have been recently described but, without data about their biological effects (Andrade-Neto et al., 2002). However, it has well been established that $P$. spicatus essential oil 
components display in vitro antibacterial activity against Pseudomonas aeruginosa and Staphylococcus aereus (Santos et al., 1997). Moreover, chalepin - purified from $P$. spicatus essential oil - complexes in vitro with glycosomal glyceraldehyde-3-phosphate dehydrogenase of $T$. cruzi - a protozoan exclusively transmitted by haematophagous triatomines like $R$. prolixus (Chagas, 1909) - disrupting the flagellate development (Mafezoli et al., 2000, Pavão et al., 2002). These observations also indicate $P$. spicatus essential oil to studies concerning the disruption of parasite development even into insect vector. Thus, it may be concluded from this preliminary study that the variety of effects of Pilocarpus spicatus essential oil on $R$. prolixus development herein described indicates its secondary metabolites, nowadays under investigation in our laboratory, as good candidates for the study of insect physiology, vector control population and perhaps, blockage of protozoan development in triatomine hosts.

\section{AKNOWLEDGMENTS}

We thank Universidade Federal Fluminense for the grants to the scientific initiation students as well as Conselho Nacional de Desenvolvimento Cientifico e Tecnológico $(\mathrm{CNPq})$ and Fundação de Apoio à Pesquisa do Estado do Rio de Janeiro (FAPERJ) for the financial support.

\section{REFERENCES}

Agra MF, França PF, Barbosa-Filho JM 2007. Synopsis of the plants known as medicinal and poisonous in Northeast of Brazil. Rev Bras Farmacogn 17: 114-140.

Amaro Luis JM, Massanet GM, Pando E, Rodriguez Luis F, Zubia E 1990. New coumarins from Pilocarpus goudotianus. Planta Med 56: 304-306.

Andrade-Neto M, Mendes PH, Silveira ER 1996. An imidazole alkaloid and other constituents from Pilocarpus trachyllophus. Phytochemistry 35: 885-887.

Andrade-Neto M, Cunha UD, Mafezoli J, Silveira ER 2000. Volatile contituents of Pilocarpus trachyllopus Holmes and Pilocarpus jaborandi Holmes (Rutaceae) from Northeast of Brazil. J Essent Oil Res 12: 768-774.

Andrade-Neto M, Cunha UD, Mafezoli J, Silveira ER 2002. Volatile constituents of different populations of Pilocarpus spicatus Saint Hill. (Rutaceae) from the Northeast of Brazil. J Essent Oil Res 14: 319-324.

Armitage P, Berry G, Matthews JNS 2002. Comparision of several groups and experimental design. In $\mathrm{P}$ Armitage, Statistical Methods in Medical Research (4 $4^{\text {rd }}$ edition), Blackwell, Oxford, p. 208-256.

Auffarth GU, Martin M, Fuchs HA, Rabsilber TM, Becker KA, Schmack I 2002. Validity of anterior chamber depth measurements for the evaluation of accommodation after implantation of an accommodative humanoptics 1CU intraocular lens. Ophthalmologe 99: 815-819.

Avancini G, Abreu IN, Saldana MDA, Mohamed RS, Mazzafera P 2003. Induction of pilocarpine formation in jaborandi leaves by sialicylic acid and methyljasmonate. Phytochemistry 63: 171-175.

Azambuja P, Garcia ES 1997. Care and maintence of triatomine colonies. In Crampton JM, Beard CB, Louid C, Molecular biology of insect disease vectors: a methods manual, Chapman and Hall, London, p. 56-64.

Bertrand C, Fare N, Moulis C 2001. Constituents of Pilocarpus trachyllophus. Fitoterapia 72: 844-847.

Bodner L, Gorsk M 1996. Parotid gland secretion of the aging rat. Arch Geron Geriatr 22: 63-69.

Bohm E, Fabel H 1987. Alternation of lung-function due to timolol, metipranolol, pindolol and pilocarpin eyedrops in patients with mild astiima bronciiale and normal adults. Klin Wochenschr 65: 920-924.

Bowers WS 1984. Insect-plants interaction: endocrine defenses. In Pitman B, Origins and development of adaptation, Ciba Foundation Symposium, London, $\mathrm{p}$. 102: 119-137.

Calcagno MP, Coll J, Lloria J, Faini F, Alonso-Amelot ME 2002. Evaluation of synergism in the feeding deterrence of some furanocoumarins on Spodoptera litoralis. J Chem Ecol 28: 175-191.

Cestari IM, Sarti SJ, Waib CM, Branco AC 2004. Evaluatin of the potential insecticide activity of Tagetes minuta (Asteraceae) essential oil against the head lice Pediculus humanus capitis (Phthiraptera : Pediculidae). Neotrop Entomol 33: 805-807.

Chagas C 1909. Nova tripanosomíase humana. Estudos sobre a morfologia e o ciclo evolutivo do Schizotrypanum cruzi n. gen., n. sp., agente etiológico de nova entidade mórbida do homem. Mem I Oswaldo Cruz 1: $159-218$.

Choi WI, Lee EH, Choi BR, Park HM, Ahn YI 2003. Toxicity of the plant essential oil to Trialeurodes vaporiorum (Homoptera : Aleyrodidae). J Econ Entomol 96: 1479-1484.

Cortez MGR, Gonzalez MS, Cabral MMO, Garcia ES, Azambuja P 2002. Dynamic development of Trypanosoma cruzi in Rhodnius prolixus: role of decapitation and ecdysone therapy. Parasitol Res 88 : 697-703.

Costa JGM, Rodrigues FFG, Angélico EC, Silva MR, Mota ML, Santos NKA, Cardoso ALH, Lemos TLG 2005. Estudo químico-biológico dos óleos essenciais de Hyptis martiusii, Lippia sidoides e Syzigium aromaticum frente às larvas do Aedes aegypti. Rev Bras Farmacogn 15: 304-309.

Craveiro AA, Andrade CHS, Matos FJA, Alencar JW 1979. Essential oil from Brazilian-Rutaceae .1. genus Pilocarpus. J Nat Prod 42: 669-671.

Craveiro AA, Fernandes AG, Andrade CHS, Matos FJA, Alencar JW, Machado MIL 1981. Óleos essenciais de plantas do Nordeste. Edições UFC, Fortaleza, 209pp.

Dias E 1943. Estudos sobre o Schyzotrypanum cruzi. Mem I Oswaldo Cruz 28: 1-110.

Edwards PJ, Wratten SD 1981. Ecologia das interações entre insetos e plantas. In Edwards PJ, Wratten SD, Temas de Biologia, EDUSP, São Paulo, 27: 71pp.

Erlich PR, Raven PH 1964. Butterflies and plants: a study in coevolution. Evolution 18: 588-608.

Fournet A, Rojas de Arias A, Charles B, Bruneton J 1996. 
Chemical constituents of essential oils of Muña, Bolivian plants traditionally used as pesticides, and their insedticidal properties against Chagas disease vectors. J Ethopharmacol 52:145-149.

Fraenkel G 1959. The raison detre of secondary plant substances. Science 129: 1466-1470.

Garcia ES 1987. The digestion of Triatominae. In: Brenner RR, Stoka AM, Chagas' Disease vectors, CRC Press, Florida, 2: p. 47-58.

Garcia ES, Azambuja P, Forster H, Rembold H 1984. Feeding and molt inhibition by azadirachtins A, B and 7-acetyl-azadirachtin A in Rhodnius prolixus nymphs. Z Naturforsch 39c: 1155-1158.

Garcia ES, Luz N, Azambuja P, Rembold H 1990. Azadirachtin depresses release of prothoracicotropic hormone in Rhodnius prolixus larvae: Evidence from head transplantations. J Insect Physiol 36: 679-682.

Garcia ES, Gonzalez MS, Azambuja P 1999. Biological factors involving Trypanosoma cruzi life cycle in the invertebrate host, Rhodnius prolixus. In: Syposium Internacional sobre Avanços no conhecimento da Doença de Chagas, 90 anos após sua descoberta. Mem I Oswaldo Cruz 94: 213-216.

Garcia ES, Azambuja P 1991. Development and interactions of Trypanosoma cruzi within the insect vector. Parasitol Today 7: 240-244.

Garcia ES, Azambuja P 2004. Lignoids in insects: chemical probes for study of ecdysis, excretion and Trypanosoma cruzi - triatomine interactions. Toxicon 44: 431-440.

Gonzalez MS, Nogueira NFS, Mello CB, de Souza W, Schaub GA, Azambuja P, Garcia ES 1999. Influence of brain on the midgut arrangement and Trypanosoma cruzi development in the vector, Rhodnius prolixus. Exp Parasitol 92: 100-108.

Gonzalez MS, Nogueira NFS, de Souza W, Azambuja P, Garcia ES 2000. Influence of brain on the Trypanosoma cruzi development in Rhodnius prolixus. Mem I Oswaldo Cruz 95: 58-59.

Gotlieb OR, Magalhães ME 1960. Modified destillation. Trap Chem Analyst 49: 114.

Guenter R 1972. The Essential Oils. In RE Krieger, Publishing Co, New York, Vol 1-6, 3894 pp.

Hoffmann F, Zhang EP 1999. Pilocarpin and latanoprost fail to prolong orthopic corneal allograft survival. Invest Ophth Vis Sci 40: 1334.

Jermy T 1966. Feeding inhibitors and food preference in chewing phytophagous insects. Entomol Exp Appl 9: 1-12.

Kaastra RC 1982. A Monograph of the pilocarpine (Rutaceae). Flora Neotrop 33: 1-198.

Katerinopoulos HE, Pagona G, Afratis A, Stratigakis N, Roditakis N 2005. Composition and insect attracting activity of the essential oil of Rosmarinus officialis. J Chem Ecol 31: 111-122.

Kelecom A, Rocha MA, Majdalani EC, Gonzalez MS, Mello CB 2002a. Novas atividades biológicas em antigos metabólitos: ácido oleanóico e eugenol de Eugenia caryophyllata. Rev Bras Farmacogn 12: 70-71.

Kelecom A, Reis GL, Fevereiro PCA, Silva JG, Santos MG, Mello CB, Gonzalez MS, Gouvea RCS, Almeida GSS 2002b. A multidisciplinary aprroach of the studie of the fluminense vegetation. An Acad Bras
Cienc 74: 171-181.

Kempf HG 1999. Pliocarpin for promoting salivation. HNO 47: 136-136.

Kollien AH, Schaub GA 2000. The development of Trypanosoma cruzi in triatominae. Parasitol Today 16: 381-387.

Krause K, Kuchle HJ, Baumgart M 1986. Comparativestudies on pilocarpin gel and pilocarpin eye drops in glaucoma patients and healthy-subjects. Klin Monatsbl Augenh 189: 341-342.

Lahiou M 2004. Methods to study the phytochemistry and bioactivity of essential oils. Phytother Res 18: 435-448.

Laurent D, Vilaseca A, Chaintrane JM, Ballivan C, Saavedra G, Ibanez R 1997. Inseticidal activity of essential oils on Triatoma Infestans. Phytother Res 11: 285-290.

Lazzari CR 1992. Circadian organization of locomotion activity in the hematophagous bug Triatoma infestans. J Insect Physiol 38: 895-903.

Lehto I 1991. Long-term prognosis of pigmentary glaucoma. Acta Ophthalmol 69: 437-443.

Link H, Bernauer K, Oberhans WE 1974. Configuration of Pilocarpus alkaloids. Helv Chim Acta 57: 2199-2200.

Lúcio EMRA, Sharapin N, França HS 2002. Estudo de alcalóides de Pilocarpus pennatifolius Lemaire. Rev Bras Farmacogn 12(Supl.): 130-131.

Mafezoli J, Vieira PC, Fernandes JB, Silva MFGF, Albuquerque S 2000. In vitro activity of Rutaceae species against the trypomastigote form of Trypanosoma cruzi. J Ethnopharmacol 73: 335-340.

Mauchline AL, Osborne JL, Martin AP, Poppy GM, Powell $\mathrm{W}$ 2005. The effects of non-host plant essential oil volatiles on the behaviour of the pollen beetle Meligethes aeneus. Entomol Exp Appl 114: 181-188.

Mulla MS, Su T 1999. Activity and biological effects of neem products against arthropods of medical and veterinary importance. J Am Mosquito Contr Assoc 15: 133-152.

Pavão F, Castilho MS, Pupo MT, Dias RLA, Correa AG, Fernandes JB, Silva MFGF, Mafezoli J, Vieira PC, Oliva G 2002. Structure of Trypanosoma cruzi glycosomal glyceraldehyde-3-phosphate dehydrogenase complexed with chalepin, a natural product inhibitor, at 1.95 angstrom resolution. Febs Lett 520: 13-17.

Pimenta ATA, Santiago GMP, Arriaga AMC, Menezes GHA, Bezerra SB 2006. Estudo fitoquímico e avaliação da atividade larvicida de Pterodon polygalaeflorus Benth (Leguminosae) sobre Aedes aegypti. Rev Bras Farmacogn 16: 501-505.

Riedler J 1992. Hypohidrotic (anhidrotic) ectodermaldysplasia in female infant. Monatsschr Kinderh 140: 398-400.

Rosche J, Maurer H, Schrebe H, Kornhuber HH 1997. Normal SEP in patients with Adie-Syndrome. Role of the Ia fibers. EEG-EMG-Zeitsc Elektroenzephalograp Elektromyogrph Verw Geb 28: 49-51.

Salyi G, Abonyi T 1994. Poisoning caused by seeds of Datura stramonium in horse - case report. Magy Allatorvosok Lapja 49: 658-662.

Santos FA, Cunha GMA, Viana GSB, Rao VSN, Manoel AN, Silveira ER 1997. Antibacterial activity of essential oils from Psidium and Pilocarpus species of plants. 
Phytother Res 11: 67-69.

Santos AP, Lopes MC, Limberger RP, Apel MA, Henriques AT, Moreno PRH 2004. Analysis of the volatile oil from Pilocarpus pennatifolius Lemmaire (Rutaceae) leaves by GH-MS. Flavour Frag J 19: 325-326.

Skopura LA 1996. Revisão taxonomica de Pilocarpus Vahl (Rutaceae) PhD Dissertation. Institute of Biosciences, University of São Paulo. São Paulo.

Skopura LA, Salatini MLF, Salatino A 1998. Hydrocarbons of leaf epicuticular waxes of Pilocarpus (Ruteaceae): Taxonimic meaning. Biochem Syst Ecol 26: 655-662.

Stoka A 1987. Ecdysteroids, juvenile hormones and metamorphosis in triatominae. Volume In: Brener R.R, Stoka AM, Chagas' Disease Vectors (Anatomic and Physiological Aspects) 2. p. 71-99.

Takano-Lee M, Edman JD 2001. Movement of Rhodnius prolixus (Hemiptera:Reduviidae) within a simulated house environment. J Med Entomol 38: 829-835.

Taveira FSN, Andrade EHA, Lima WN, Maia JGS 2003. Seasonal variation in the essential oil of Pilocarpus microphyllus Stapf. An Acad Bras Cienc 75: 27-31.

Tuetun B, Choochote W, Rattanachanpichai E, Chaithong U, Jitpakdi A, Tippawangkosoi F, Riyong D, Pitasawat B 2004. Mosquito repellency of the seeds of celery (Apium graveolens L.). Ann Trop Med Parasitol 98: 407-417.

Tunc I, Erler F 2003. Repellency and repellent stability of essential oil constituents against Tribolium confusum. Z Pflanzenk Pflanzen 110: 394-400.

Vieira PC, Mafezoli J, Pupo MT, Fernandes JB, Silva MFGF, Albuquerque S, Oliva G, Pavão F 2001. Strategies for the isolation and identification of trypanocidal compounds from the rutales. Pure Appl Chem 73: 617-622.

Vilaseca A, Guy I, Charles B, Guinaudeau H, Arias AR, Fournet A 2004. Chemical composition and insecticidal activity of Hedeoma mandoniana essential oil. $J$ Essent Oil Res 16: 380-383.

Wamil A, Croiset G, Kleinrok Z, Dewied D 1989. Beneficialeffects of ACTH 4-10 on pilocarpin induced seizures. Neurosci Res Commun 4: 109-116.

Wheller GS 2005. Maintenace of narrow host range by Oxyops vitiosa; a biological control agent of Melaleuca quinquenervia. Biochem Syst Ecol 33: 365-383.

Wigglesworth VB 1934a. The physiology of ecdisis in Rhodnius prolixus (Hemiptera) II. Factors controlling moulting and metamorphosis. Quart J Micr Sci 77: 191-222.

Wigglesworth VB 1934b. Factors controlling moulting and metamorphosis in an insect. Nature 135: 725-726.

Wigglesworth VB 1943. The fate of haemoglobin in Rhodnius prolixus (Hemiptera) and other blood-sucking arthropods. Proc Roy Soc London 131: 313-339.

Wigglesworth VB 1972. The principles of insect physiology. $7^{\text {th }}$ ed., Chapman; Hall, London. Muscular system and locomotion p. 146-177.

Yermakova VN, Konde LA, Davydova NG, Buromskaya LM, Malyuta GD 1991. Anaprilin efficacy in the treatment of glaucoma. Vestn Oftalmol 1: 9. 